\title{
Keywords in Written Academic Legal Texts: A Corpus-Derived List
}

\author{
Abdullah A. Alasmary ${ }^{1}$ \\ ${ }^{1}$ Department of English Language \& Translation, College of Languages and Translation, King Saud University, \\ Riyadh, Saudi Arabia
}

Correspondence: Abdullah A. Alasmary, King Saud Universty, Riyadh, Saudi Arabia. E-mail: aasmary@KSU.EDU.SA

Received: February 10, 2019 Accepted: March 3, 2019 Online Published: April 6, 2019

doi:10.5539/ijel.v9n3p40 URL: https://doi.org/10.5539/ijel.v9n3p40

\begin{abstract}
This study presents the Written Academic Legal Vocabulary (WALV), a discipline-specific genre-focused list of keywords in a corpus of academic legal texts. To generate this list, a purpose-customized corpus of full-length academic texts is created and analyzed with the help of corpus-based analytical tools. Items on the list are chosen based on criteria such as frequency of occurrence, range and keyness. The keywords recur more frequently in a specialized corpus than in a general reference corpus, a finding that attests to the pedagogical utility of these expressions as possible focus of explicit instruction. The final list consists of 298 headwords and 219 families (lemmas). Findings also indicate that the list includes words belonging to different grammatical types, the most common of which are nouns. The list also incorporates a large number of abbreviations, shortenings and acronyms.
\end{abstract}

Keywords: keywords, legal discourse, corpus linguistics, academic vocabulary

\section{Introduction}

Legal language requires that learners, particularly those for whom English is a second or foreign language, exhibit a greater understanding of and familiarity with a wide range of specialized vocabulary. However, gaining control over a large inventory of such vocabulary is not an easy task, given the general consensus among scholars that students find it challenging to achieve specific reading and writing purposes due to deficiencies in their lexical knowledge (Lei \& Liu, 2016). The literature on teaching and learning second language vocabulary is replete with tips and techniques on how to expand learners' lexical knowledge. One way to support learners' lexical knowledge is to draw their attention to key lexical items typical of a specific discipline (e.g., Coxhead, 2000; West, 1953). Not only were these lists received with appreciation, but they also made their way into second language pedagogy: textbooks, methodology manuals and teaching resources.

The study of legal language has attracted the attention of several researchers (Berman, 2013; Bhatia, 1987; Maley, 1994; Tiersma, 2000; Williams, 2004). The central rule that language plays in the legal discourse is captured by Maley (1994, p. 11) who maintains that language is the "medium, process and product in the various arenas of the law where legal texts, spoken or written, are generated in the service of regulating social behavior". In a similar vein, Berman (2013, p. 87) holds that language is implicated in several legal discourse settings including "law-making, judging, regulating, negotiating, and other processes of creating, changing, or terminating rights and duties". Tiersma $(2000$, p. 4) points out that legal language is increasingly seen as "a monolithic system" which "exhibits greater variation, depending on the place where it is used, whether it is written or spoken, the level of formality, the genre in which it appears, and other factors". Several legal terms in English, Tiersma (2000) adds, can be traced back to Latin (e.g., actus reus) or French (e.g., misdemeanor). In a much register-focused study, Williams (2004) explores the characteristics of written legal English, concluding that the specialized nature of vocabulary represents a challenge for non-experts as it contains several archaic expressions (e.g., hereinafter and darraign) and words of Latin and French origin (e.g., attainder and profits à prendre). On a sentence level, Williams (2004) observes that legal writings are inherently complex, relatively long and highly impersonal and contain a great number of passivized forms and nominal patterns.

In a seminal work, Bhatia (1987) discusses the distinctive attributes of the legal language, dividing it into spoken and written, with each branching out into smaller sub-types. The spoken legal language, on the one hand, is represented by lectures and moots, student-student interactions, client-lawyer discussions, talks between 
counsels and witnesses, and jury instructions. The written legal language, on the other hand, includes three major forms: academic, juridical and legislative. Journals and textbooks represent the academic language whereas cases and judgements denote juridical language. Legislations involve several forms of writings, including contracts, agreements, rules and regulations. By focusing on a specific register (law) and a specific genre type (full-length textbooks), this study aims to present legal students and practitioners with a corpus-derived list of keywords which occur more often in a specialized group of texts than in a larger, though general, reference corpus.

A robust way of unveiling important vocabulary in a corpus of naturally-occurring language is to adopt a keyword approach (see Bondi \& Scott, 2010). In this model, key vocabulary refers to "words which are significantly more frequent in a sample of text than would be expected, given their frequency in a large general reference corpus" (Stubbs, 2010, p. 25). Using this approach as a framework, this study hopes to present to language educators, materials designers and textbooks authors with a resource of key vocabulary typical of the legal language that can be used in contexts of language training programs and preparatory sessions.

\section{Overview of Academic Vocabulary}

Academic vocabulary has been the subject of extensive scholarly activity throughout the past decades (for a review see Nagy \& Townsend, 2012). Knowledge of academic English vocabulary is essential for mastering a wide range of skills such as reading comprehension (Qian, 2002), speech (Dang, 2018; Dang \& Webb, 2014), reading and writing (Malmström, Pecorari \& Shaw, 2018) and general language proficiency (Webb \& Paribakht, 2015). Developing a thorough understanding of and familiarity with academically oriented words and expressions has long been a goal of language preparation programs and intensive English language courses. Mastery of academic vocabulary allows non-native English students and novices to navigate complex texts in their specialist fields and to contribute to the construction and dissemination of discipline-specific knowledge (Nation, 2013). Possessing receptive as well as productive knowledge of domain-specific vocabulary is not an easy task, given the wide-ranging scope of this type of vocabulary, on the one hand, and the scarce classroom time that is available to practitioners, on the other hand.

Nation (2013) argues that it is important for second language learners to demonstrate knowledge of a wide array of academic vocabulary. The importance of this type of vocabulary, Nation continues to argue, lies in four factors. First, "academic vocabulary is common to a wide range of academic texts, and not so common in non-academic texts". As for the second factor, vocabulary of academic nature "accounts for a substantial number of words in academic texts" (Nation, 2013, p. 291). A third factor is that academic vocabulary is not as "well-known as technical vocabulary" (p. 292), implying that learners are more likely to skip academic words and expressions and focus more on technical vocabulary. Finally, instructional intervention is expected to be successful, given the nature of this vocabulary which does not require specialist background from the part of instructors.

There have been several attempts to foster knowledge of academic vocabulary (Alamri \& Rogers, 2018; Horst, Cobb, \& Nicolae, 2005; Scammacca \& Stillman, 2018; Thurston \& Candlin, 1998). One way to help ESL students recall the meanings of academic words and less known expressions is to offer them access to a web-based platform where they can acquire knowledge of these lexical items and participate in a series of interactive activities that help in the productive use of the recently acquired vocabulary (Horst et al., 2005). In a similar vein, Thurston and Candlin (1998) allowed university-level students to access a concordance program in order to enhance knowledge of expressions of general academic use. Opinions gleaned from the students indicated that exposure to this type of vocabulary instruction is conducive to better retention of academic lexis. Alamri and Rogers (2018) tested several explicit ways of teaching technical and academic vocabulary and concluded that pre-instructional exposure to domain-specific terms with the help of a visual aid had a positive impact on the learning of academic vocabulary. Repeated exposure to subject-matter vocabulary is investigated by Scammacca and Stillman (2018) who noticed that allowing low-level students the opportunity to read texts several times made them aware of a wide range of vocabulary in the domain of social studies.

These studies seem to concur that there are several ways instructors can draw on to foster knowledge of academic vocabulary. One approach is to synthesize a pedagogically sound list of key academic words and expressions that can be used to inform classroom practices. The following section sheds light on some studies which have produced listings of academic and technical vocabulary throughout the past years.

\section{Lists of Academic Vocabulary}

The need to build lists of key vocabulary takes root in the seminal work of West (1953) whose pioneering attempt has drawn the attention of scholars from a range of different specialties. Despite its profound influence, West's General Service List (GSL) is not without problems, the most obvious of which is the presence of some function words whose meanings pose no challenge to the students. Another attempt to create a list of useful 
vocabulary was carried out by Coxhead (2000) who, considering the students' academic needs, created a 3.5-million-word corpus representing four key domains: art, commerce, law and science. Although Coxhead's Academic Word List (AWL) is more specialized than the GSL, thus accounting for items of academic nature, it is criticized for overlooking differences in vocabulary use within domains. A third notable list of key vocabulary was produced by Gardner and Davies (2014) who suggested a 500-word list of academic vocabulary based on a 120-million-word corpus representing a range of disciplines such as education, humanities, history, medicine and health, and law and political science. The list is comprised of items of different types which are elicited according to a set of predefined criteria such as range, frequency and the academic nature of the word. Words in the list are assigned to grammatical categories such as verbs (e.g., provide, include and develop), nouns (e.g., study, group, system) and adjectives (e.g., social, important, human).

The criticism leveled against the use of a general-purpose discipline-transcending list of vocabulary for fostering lexical knowledge irrespective of the field of the study (Hyland \& Tse, 2007) has apparently encouraged scholars to investigate vocabulary in a range of domains such as medicine (Lei \& Liu, 2016; Wang, Liang, \& Ge, 2008), nursing (Yang, 2015) engineering (Watson Todd, 2017), agriculture (Martínez, Beck, \& Panza, 2009), pharmacology (Grabowski, 2015) and finance (Tongpoon-Patanasorn, 2018). Martínez et al. (2009) contrasted a list of words from a corpus of journal articles in the field of agriculture to items on Coxhead's (2000) list, reporting that a total of 1941 word types uncovered in the agriculture list are also found in the AWL. These shared word types are not evenly distributed across $t$ the journal subparts, as the Results Section has the lowest number of types and the Discussion Section has the highest number. With respect to the meanings conveyed by these lexical items, the analysis shows that the same word in both lists may convey different meanings. For example, the word culture carries a different meaning in agriculture than in humanities, thus alerting specialists to the fact that even in cases where the same word occurs across disciplines, it should be noted that the meaning may differ according to the context under study. Lei \& Liu (2016) compiled a list of academic words in the medical domain by applying a series of selection and filtering criteria. Drawing on a 2.7-million-word corpus of medical journal articles, the list is compared against a similar domain-specific corpus made up of textbooks. The list is comprised of 819 lemmas, half of which of which are nouns, 219 adjectives, 133 verbs and 23 adverbs. The list is said to offer "substantially more coverage while containing significantly fewer items" (p. 47). Yang (2015) developed a 676-item list of vocabulary expressions in a corpus of journal articles in the field of nursing. The list is built around word families which are both highly frequent and widely distributed.

A prime concern for the lists compilers has been the approach that they take when identifying and selecting words for the list from a corpus of naturally-occurring content. For example, Grabowski (2015) used a corpus with four divisions, each of which represents a distinct subgenre of the pharmacological studies. The next step was to use a software program to generate a keyword list typical of each sub-register by comparing the items on the keyword list against other corpus subparts. Lei and Liu (2016) applies a series of criteria, among the most important of which are the frequency of occurrence, distribution across texts making up the entire corpus and the extent to which the sequence fulfills a discipline-specific meaning. Tongpoon-Patanasorn (2018) appears to supplement her corpus-derived list with opinions of experts regarding the potential usefulness of the items for classroom teaching.

Despite the intense scholarly activity shaping the domain of the English for Specific/Academic Purposes (ESP/EAP) nowadays, it seems clear that legal studies have not received much attention. This study is expected to provide the legal community and the English instructors with a list of key vocabulary. To narrow the scope of the study, the list includes items derived from written academic texts, as these text types are expected to be encountered in various academic contexts. The list components are synthesized and discussed using a combination of corpus tools and genre analysis.

\section{Methodology}

This section sheds light on the corpora that are used to generate the list of words typical of the legal discourse. The second part is concerned with the refinement procedures taken to address some problems with retrieval of some items.

\subsection{Corpora}

This study draws on a 10-million-word corpus of written, full-length academic texts in the legal domain (see Table 1). Hyland (2009, p. 112) points out that academic textbooks are "indispensable to academic life, facilitating the professional's role as a teacher and constituting one of the primary means by which the concepts and analytical methods of a discipline are acquired". Textbooks as such have a number of situational characteristics (Biber \& Conrad, 2009). They are normally written by professionals and are intended to address a 
wider base of scholarly readership, including novices and less informed specialists. Textbooks come in a writing format and, unlike other registers such as speech, are subjected to rounds of revising, editing, proofreading, deletion and addition before they are available as a final product. In terms of their communicative purposes, textbooks seem to convey information and clarify concepts, thus combining both descriptive and explanatory features.

Texts making up the study corpus (SC) amount to fifty-five and cover a wide range of legal areas such as private law, internet law, cooperative law, European criminal law, international economic law, human rights law and energy law. Although this study strives to attain a higher level of representativeness, thus drawing on several legal areas, it should be noted that this corpus is not comprehensive enough to account for all divisions of the legal discourse, as such goal is difficult to fulfil, given the diversity of the discipline, on the one hand, and the wide-ranging scope of legal genres, on the other hand. Selected texts for analysis are cleared from the publishers' information, table of contents, table of figures, references, and table of cases and statutes (but not the cases and statutes themselves) prior to corpus treatment.

To elicit keywords typical to the legal domain, it is necessary to use a reference corpus (RC). The written section in the British National Corpus (BNC) is chosen as a reference corpus against which patterns in the study corpus are compared and contrasted. With a size totaling 100-million words, the BNC is "one of the largest and most representative corpus of general English currently available" (Durrant \& Schmitt, 2009, p. 166). The reference corpus is approximately eight times larger than the study corpus, and the selection of a large reference corpus to detect keywords in a study corpus is a methodologically robust way, as is pointed out by Scott and Tribble (2006).

Keyness is calculated using WordSmith Tools 7, a software program which allows for a list of words in the Study Corpus to be generated using the WordList Function. Then the Keyword Function is used to compare the frequency of each word in the previously generated wordlist in the (SC) against the frequency of the same word in the reference corpus (RC). Keywords are elicited using log likelihood test with a minimum frequency of 25 times per million word and $p$ value adjusted at 0.000001 .

\subsection{List Refinement}

The corpus-derived list of the keywords in the corpus is not without problems. First, the list includes names of well-known regions, countries and cities such as Canada, Australia, Britain, the Netherlands, Europe, Berlin, the Hague and Geneva. Names of countries are deleted from the list as they pose no challenge to the students. Other words which are of no pedagogical value to the students either because they are quite common (e.g., internet) or are context-dependent proper names (e.g., Springer) are also removed from the list. These refinement procedures are carried out to ensure that items on the list are useful for the students with different study goals: furthering their subject-matter knowledge, pursuing an academic degree or participating in a career development program.

Table 1. Corpora description

\begin{tabular}{lll}
\hline Key statistics & Study Corpus (SC) & Reference Corpus (RC) \\
\hline Tokens (running words) & $10,178,964$ & $87,814,984$ \\
Tokens used for word list & $9,469,708$ & $86,402,664$ \\
Types (distinct words) & 6,401 & 338,302 \\
type/token ratio (TTR) & 0.07 & 0.39 \\
Standardized TTR & 36.77 & 43.16 \\
Mean word length (in characters) & 4.88 & 4.72 \\
Word length std.dev. & 2.72 & 2.60 \\
\hline
\end{tabular}

\section{Results}

The analysis of the legal corpus has led to the retrieval of 499 headwords and 242 families which make the academic legal list (WAVL). In this section, items on the list will be compared against similar items in three academic lists, namely the Academic Word list (AWL), the General Service List (GSL) and the Academic Vocabulary List (AVL). Then, the legal vocabulary included in the first hundred words will be discussed with a particular attention being paid to some tendencies in the list.

\subsection{Comparison with the AWL, GSL and AVL}

Academic Legal List of keywords meeting the criteria for inclusion is presented in the Appendix. Since the purpose of this research is to provide learners with a manageable set of key vocabulary items, the list is 
shortened to approximately 500 headwords and 242 families. The total occurrences of the headwords amount to $1,322,789$ million times, accounting for $13.9 \%$ of all tokens in the corpus. Such percentage is greater than Coxhead's (2000) estimate which reported that items on the Academic Word List covered $10 \%$ of all tokens in her 3-million corpus of academic materials. This discrepancy may be due to differences in the components of each corpus, as the present study draws on texts specific to law and legal studies whereas Coxhead's corpus comprises texts of distinct academic areas. Another reason lies in the differences in the corpus size, as it is clear that the corpus upon which this study is based is three times larger than that of Coxhead. As can be seen in Table 2, there are thirty-two words in Coxhead's list that are also found in our list. Examples of these words include nouns such as access, principle and chapter, verbs such as establish, submit and conclude, and adjectives such as valid, adequate and legal. When compared with West's (1953) General Service List, it becomes clear that there is much overlapping between items in both lists. The number of words that are found in the West's GSL and our list amounts to eighty-six (see Table 3). Examples of shared words include court, moral, reasonable, law and case. The greatest number of shared items is found between the WAVL list and that of Gardner and Davies' (2014), with a total of 135 words occurring in both lists. The top 40 overlapped words are reported in Table 4 .

The legal list of key academic vocabulary incorporates headwords and families. The word law, for example, appears first in the list since it occurs far more frequently than the three other related forms: laws, lawful and unlawful. Presenting different forms of the same word offers the students and professionals the knowledge they need about a range of rhetorical devices that can be used for different communicative purposes in the legal domain.

Table 2. Words found in the WAVL and AWL

\begin{tabular}{lll}
\hline word & word & word \\
\hline access & clause & internal \\
context & commission & justify \\
establish & conclude & legal \\
principle & conduct & mechanism \\
submit & consent & participate \\
valid & contract & prior \\
code & criteria & promote \\
adequate & ensure & regime \\
chapter & framework & regulate \\
circumstance & implement & specific \\
civil & impose & \\
\hline
\end{tabular}

Table 3. Shared words in WAVL list and GSL

\begin{tabular}{lll}
\hline word & word & word \\
\hline court & purpose & exception \\
moral & property & arrest \\
reasonable & criminal & harm \\
law & justice & citizen \\
case & financial & mechanism \\
member & duty & remedy \\
international & agency & republic \\
rule & safety & lawyer \\
article & respect & universal \\
decision & program & customary \\
person & review & interference \\
apply & prevent & weapon \\
shall & & \\
\hline
\end{tabular}


Table 4. Shared words in the WAVL and AVL (lemma)

\begin{tabular}{llll}
\hline word & word & word & word \\
\hline form & assistance & support & standard \\
focus & resolution & organization & design \\
individual & result & increase & state \\
establish & experience & general & recognize \\
act & human & article & context \\
apply & thus & determine & relation \\
range & control & present & concept \\
conduct & international & measure & design \\
journal & individual & specific & purpose \\
specifically & support & author & benefit \\
\hline
\end{tabular}

\subsection{Overview of the List Components}

A quick look at the list reveals that it is dominated by nouns, representing roughly $75 \%$ of all words in the first one hundred words. Other forms are also represented, including verbs, adjectives and adverbs. The list also consists of a great deal of abbreviated forms, acronyms and shortenings.

The ubiquitous use of nouns is a distinct feature of the legal text. The list comprises a large number of nouns and fewer verbs and adjectives. The grammatical status of certain expressions can be determined only if concordance lines are checked, as they may belong to more than one grammatical category (e.g., conduct). The singular form of some nouns recurs more frequently than the plural form, giving an indication that the emphasis has been placed on single instances rather than collective ones. The noun law, for example, is encountered 60,000 times whereas the plural form laws is seen only 7000 times. This holds true with several other forms such as state, court, member, article, rule and principle in which the singular form recurs far more frequently than the plural form. Several nouns in the first 100 words have undergone a process of nominalization in which "verbs are transformed into nouns" (Williams, 2004, p. 115). Examples include nouns such as decision, protection, organization and drafting.

Beside nouns, the list comprises a large number of adjectives, the most recurrent of which are legal, international and cooperative. Some adjectives help characterize certain laws such as international, general, federal and civil whereas some others appear to provide more details about the nouns modified by these adjectives (e.g., limited, relevant and specific). Some other adjectives help show more about the distinctive characteristics of the following nouns. Examples include expressions such as mutual, general and moral.

It is clear from the list (see the Appendix) that verbs occur far less frequently than nouns and adjectives. The first verb form in the list is apply which reflects a state of action by parties for whom a specific legislation has been created. The modal verb shall is characteristic of the legal discourse as it is communicatively used to spell out regulations and assign rights and obligations (Breeze, 2013). Other verbs in the list such as conduct, respect, establish and ensure appear to emphasize the binding nature of rules and legislation.

The keywords list contains a number of acronyms, abbreviations and shortenings which need to be explained by referring the students to the full range of words represented by these acronyms. Some of the abbreviated forms stand for government agencies and international organizations such as the European Court of Justice (ECJ), International Civil Aviation Organization (ICAO), the Department of Justice (DOJ) and International Atomic Energy Agency (IAEA), while others refer to treaties and legislations such as TEFU (Treaty on the Functioning of European Union) and ECLI (European Case Law Identifier). The list also consists of common scholarly abbreviations and symbols such as sec for section, cha for chapter, and vol for volume. Some of the abbreviations represent similar entities such as $B E R$ and $D E R$, which are used to refer to both basic encoding rules and distinguished encoding rules, respectively. It is worth mentioning that a single abbreviation may refer to two different entities, depending on the context in which it occurs. An example includes the abbreviation IAEA which can be interpreted as denoting to either the International Atomic Energy Agency or Independent Administration of Estates Acts. If left unexplained, these abbreviations will present a challenge for the students who may revert to inaccurate guessing.

\section{Discussion}

The purpose of this paper is to generate a list of key vocabulary that can be incorporated into an ESP or EAP course or training program for law students and non-native English professionals who aspire to expand their knowledge of legal language. The list of key academic words comprises a total of 498 headwords and 219 
families. The coverage of headwords in the corpus, as is computed by the total number of occurrences, is at $13 \%$, a proportion higher than the one reported by Coxhead (2000). It seems clear that the list is dominated by words and expressions typical of the legal discourse, a finding that is consistent with the conclusion noted by Hyland and Tse (2007) who doubted the usefulness of general vocabulary lists and called for more domain-specific ones that meet the needs of individual learners.

Although the list is generated from domain-specific texts, it seems clear that there is some overlapping between items here and items compiled by West (1953), Coxhead (2000) and Gardner and Davies (2014). Domain-transcending expressions include examples such as clause, submit, purpose and form. The presence of these items across different lists may be interpreted in two different ways. First, it seems clear that some items here carry different senses. The word clause is used in legal contexts to refer to a specific item in a legislation. This is rather different in a domain such as linguistics where the term clause is used to indicate a grammatical unit larger than the phrase. Another reason lies in the fact that some items are more likely to occur in several disciplines, given their broader rhetorical function in the written discourse (e.g., assume).

Another group of words in the list carry technical meanings. The words article and code are assigned highly specialized meanings that are tied to the legal discourse. When these two terms are used in domains such as linguistics and computer programing, they are more likely to convey different senses. The tendency for some expressions to have domain-specific meanings has been noticed by some researchers. Martínez et al. (2009) pointed out that the word culture in a corpus of texts on agriculture had a rather different, more specialized meaning. The list compiled by Grabowski (2015) has also similar terms that have dual meanings, that is, one general meaning and another more specialized one. The meanings fulfilled by expressions such as trial and investigation are largely typical of pharmacology where a specific medication undergoes extensive trial and experimentation before being produced for the public use.

Another tendency in the list is the prolific use of subject-matter abbreviations, shortenings and acronyms. Technical writing manuals (e.g., Tebeaux \& Dragga, 2015) make a distinction between three types: abbreviations, acronyms and shortenings. Abbreviated forms such as the UK and the USA are spelled as single letters whereas acronyms such as the UNICEF are produced as words. The third type involves shortenings which consist of two or three letters representing a full-length expression. The list has several short forms such as vol. for volume, sec. for section and chap. for chapter.

\section{Pedagogical Implications}

There are several methodological and pedagogical implications of this study. Instructors can draw on the list for preparing vocabulary-focused materials. The procedure may involve categorizing items into grammatically distinct groups, that is, nouns are extracted and placed in a single group, verbs in second group, adjectives in a third group and so on. It is also possible that instructors select words that pose a challenge for learners and make a list of activities that alert learners to the meanings served by these items. Another implication is for textbook authors and materials designers who may find the list a good starting point while preparing ESL programs. Items on the list could also be used to measure the extent to which ESP and EAP materials deal with discipline-specific lexical knowledge. Finally, the list could be used to inform writing instruction in ESP/EAP contexts. It seems clear from some previous research (e.g., Candlin, Bhatia, \& Jensen, 2002) that written legal content is not accessible for some students. Words presented in the WALV can be delivered using a freely accessible platform for learning and practice.

\section{Conclusion}

This study presents a discipline-specific genre-focused list which contains lexical items typical of the type of vocabulary normally encountered by the students and professionals in the domain of academic legal studies. The selection of items is driven by frequency of occurrence, range and keyness. The analysis of the corpus has uncovered a total of 498 headwords and 219 families. The pedagogical usefulness of items in the list, however, can be further strengthened if a "hybrid approach" (Tongpoon-Patanasorn, 2018) is pursued. In this approach, the corpus-derived list is presented to a group of experts in order to rank-order all lexical items on a scale of usefulness. Items which rank higher on the keyness scale, but are judged as unimportant or irrelevant by the panel of experts, are excluded from the final list. The list presented in this study can be useful for the students of law and legal studies, textbook authors, materials designers and language instructors. They can draw on items on the list while preparing language-preparation materials or teaching an English for Academic Purposes course.

\section{Acknowledgement}

The Author extends his appreciation to the Deanship of Scientific Research at King Saud University for funding 
this work through the Research Project No R5-16-01-31.

\section{References}

Alamri, K., \& Rogers, V. (2018). The effectiveness of different explicit vocabulary-teaching strategies on learners' retention of technical and academic words. The Language Learning Journal, 46(5), 622-633. http://doi.org/10.1080/09571736.2018.1503139

Berman, H. J. (2013). Law and Language: effective symbols of community. Cambridge University Press. https://doi.org/10.1017/CBO9781139519717

Bhatia, V. K. (1987). Language of the law. Language Teaching, 20(4), 227-234. https://doi.org/10.1017/S026144480000464X

Biber, D., \& Conrad, S. (2009). Register, genre, and style. Cambridge: Cambridge University Press. https://doi.org/10.1017/CBO9780511814358

Bondi, M., \& Scott, M. (2010). Keyness in texts (Vol. 41). Amsterdam: John Benjamins Publishing. https://doi.org/10.1075/scl.41

Breeze, R. (2013). Lexical bundles across four legal genres. International Journal of Corpus Linguistics, 18(2), 229-253. https://doi.org/10.1075/ijcl.18.2.03bre

Candlin, C. N., Bhatia, V. K., \& Jensen, C. H. (2002). Developing legal writing materials for English second language learners: problems and perspectives. English for Specific Purposes, 21(4), 299-320. https://doi.org/10.1016/S0889-4906(01)00029-1

Coxhead, A. (2000). A New Academic Word List. TESOL Quarterly, 34(2), 213. https://doi.org/10.2307/3587951

Dang, T. N. Y. (2018). The nature of vocabulary in academic speech of hard and soft-sciences. English for Specific Purposes, 51, 69-83. https://doi.org/10.1016/j.esp.2018.03.004

Dang, T. N. Y., \& Webb, S. (2014). The lexical profile of academic spoken English. English for Specific Purposes, 33(1), 66-76. https://doi.org/10.1016/j.esp.2013.08.001

Durrant, P., \& Schmitt, N. (2009). To what extent do native and non-native writers make use of collocations? International Review of Applied Linguistics in Language Teaching, 47(2), 157-177. https://doi.org/10.1515/iral.2009.007

Gardner, D., \& Davies, M. (2014). A New Academic Vocabulary List. Applied Linguistics, 35(3), 305-327. https://doi.org/10.1093/applin/amt015

Grabowski, Ł. (2015). Keywords and lexical bundles within English pharmaceutical discourse: A corpus-driven description. English for Specific Purposes, 38, 23-33. https://doi.org/10.1016/j.esp.2014.10.004

Horst, M., Cobb, T., \& Nicolae, I. (2005). Expanding Academic Vocabulary with an Interactive On-Line Database. Language Learning \& Technology, 9(2), 90-110.

Hyland, K. (2009). Academic discourse. London: Continuum.

Hyland, K., \& Tse, P. (2007). Is there an "academic vocabulary"? TESOL Quarterly, 41(2), 235-253. https://doi.org/10.1002/j.1545-7249.2007.tb00058.x

Lei, L., \& Liu, D. (2016). A new medical academic word list: A corpus-based study with enhanced methodology. Journal of English for Academic Purposes, 22, 42-53. https://doi.org/10.1016/j.jeap.2016.01.008

Maley, Y. (1994). The language of the law (J. Gibbons, Ed.). New York: Routledge.

Malmström, H., Pecorari, D., \& Shaw, P. (2018). Words for what? Contrasting university students' receptive and productive academic vocabulary needs. English for Specific Purposes, 50, 28-39. https://doi.org/10.1016/j.esp.2017.11.002

Martínez, I. A., Beck, S. C., \& Panza, C. B. (2009). Academic vocabulary in agriculture research articles: A corpus-based study. English for Specific Purposes, 28(3), 198. https://doi.org/10.1016/j.esp.2009.04.003

Nagy, W., \& Townsend, D. (2012). Words as Tools: Learning Academic Vocabulary as Language Acquisition. Reading Research Quarterly, 47(1), 91-108. https://doi.org/10.1002/RRQ.011

Nation, I. S. P. (2013). Learning vocabulary in another language. Cambridge: Cambridge University Press. https://doi.org/10.1017/CBO9781139858656 
Qian, D. (2002). Investigating the relationship between vocabulary knowledge and academic reading performance: An assessment perspective. Language Learning, 52(3), 513-536. https://doi.org/10.1111/1467-9922.00193

Scammacca, N. K., \& Stillman, S. J. (2018). The Effect of a Social Studies-Based Reading Intervention on the Academic Vocabulary Knowledge of below-Average Readers. Reading \& Writing Quarterly, 34(4), 322 337. https://doi.org/10.1080/10573569.2018.1446855

Scott, M., \& Tribble, C. (2006). Textual patterns: key words and corpus analysis in language education. Amsterdam: John Benjamins Publishing Company. https://doi.org/10.1075/scl.22

Stubbs, M. (2010). Three concepts of keywords. In M. Bondi \& M. Scott (Eds.), Keyness in texts (pp. 21-42). Amsterdam: John Benjamins Publishing Company. https://doi.org/10.1075/scl.41.03stu

Tebeaux, E., \& Dragga, S. (2015). The essentials of technical communication. Oxford, UK: Oxford University Press Oxford.

Thurston, J., \& Candlin, C. N. (1998). Concordancing and the teaching of the vocabulary of academic English. English for Specific Purposes, 17(3), 267-280. https://doi.org/10.1016/S0889-4906(97)00013-6

Tiersma, P. M. (2000). Legal language. University of Chicago Press.

Tongpoon-Patanasorn, A. (2018). Developing a frequent technical words list for finance: A hybrid approach. English for Specific Purposes, 51, 45-54. https://doi.org/10.1016/j.esp.2018.03.002

Wang, J., Liang, S., \& Ge, G. (2008). Establishment of a Medical Academic Word List. English for Specific Purposes, 27(4), 442-458. https://doi.org/10.1016/j.esp.2008.05.003

Watson, T. R. (2017). An opaque engineering word list: Which words should a teacher focus on? English for Specific Purposes, 45, 31-39. https://doi.org/10.1016/j.esp.2016.08.003

Webb, S., \& Paribakht, T. S. (2015). What is the relationship between the lexical profile of test items and performance on a standardized English proficiency test? English for Specific Purposes, 38, 34-43. https://doi.org/10.1016/j.esp.2014.11.001

West, M. (1953). A general service list of English words. London: Longman.

Williams, C. (2004). Legal English and plain language: An introduction. ESP Across Cultures, 1(1), 111-124.

Yang, M.-N. (2015). A nursing academic word list. English for Specific Purposes, 37, 27-38. https://doi.org/10.1016/j.esp.2014.05.003

\section{Appendix A}

\begin{tabular}{lll}
\hline No & Key Word & Lemmas/explanation of short forms \\
\hline 1. & Law & Laws, unlawful, lawful \\
2. & State & Stated, states, stating \\
3. & Case & cases \\
4. & Court & Courts, court's \\
5. & Legal & Legally, legality \\
6. & Member & Members, membership \\
7. & Rights & \\
8. & International & Internationally \\
9. & Rule & Ruled, rules, RUL \\
10. & Article & Articles, Art \\
11. & Decision & decisions \\
12. & Act & acts \\
13. & Cooperative & Cooperatives, Cooperation \\
14. & Person & persons \\
15. & Para (paragraph) & Paras, Paragraph, paragraphs \\
16. & General & \\
17. & Principle & principles \\
18. & Regulation & regulations, regulate \\
& & regulate, regulated, regulates, regulating \\
19. & ET (et al) and others & \\
20. & Protection & Protect, protected, protecting, protects \\
21. & Human & Humanitarian, Humanity \\
22. & Apply & application, applied, applying \\
23. & Provision & Provisions, Provisional \\
\hline
\end{tabular}




\begin{tabular}{|c|c|c|}
\hline 24. & Contract & Contracting, contracts, contractual \\
\hline 25. & Shall & \\
\hline 26. & Commission & Commissioner \\
\hline 27. & Agreement & agreements \\
\hline 28. & Organization & Organizations, organizational \\
\hline 29. & Purpose & purposes \\
\hline 30. & Regard & Regarding [, regards, regardless \\
\hline 31. & Thus & \\
\hline 32. & Property & \\
\hline 33. & Convention & Conventions \\
\hline 34. & Treaty & Treaties [1617] \\
\hline 35. & $\mathrm{PP}$ & From Latin (Per procurationem) meaning by agency, that is, signing on behalf of other. \\
\hline 36. & Competition & \\
\hline 37. & Obligation & obligations \\
\hline 38. & Risk & risks \\
\hline 39. & Framework & frameworks \\
\hline 40. & Criminal & Criminality \\
\hline 41. & Civil & \\
\hline 42. & Requirement & Requirements, require, requires, requiring \\
\hline 43. & Procedure & Procedures \\
\hline 44. & Justice & justice \\
\hline 45. & Security & securities \\
\hline 46. & Measures & \\
\hline 47. & Parties & \\
\hline 48. & ECLI & European Case Law Identifier \\
\hline 49. & ECI & Effectively Connected Income \\
\hline 50. & Access & accessed \\
\hline 51. & Activities & \\
\hline 52. & Financial & \\
\hline 53. & Copyright & \\
\hline 54. & Directive & directives \\
\hline 55. & Liability & Liable, liabilities \\
\hline 56. & Duty & duties \\
\hline 57. & Relevant & Relevance \\
\hline 58. & Specific & \\
\hline 59. & SEQ & "and the following \\
\hline 60. & $\mathrm{EC}$ & European Commission \\
\hline 61. & Legislation & \\
\hline 62. & Chapter & \\
\hline 63. & Related & \\
\hline 64. & Basis & \\
\hline 65. & Adopt & Adopted, adopting \\
\hline 66. & Conduct & Conducted, conducting \\
\hline 67. & Agency & Agencies \\
\hline 68. & Victim & victims \\
\hline 69. & Recognition & \\
\hline 70. & Safety & \\
\hline 71. & Mutual & \\
\hline 72. & Interests & \\
\hline 73. & Cannot & \\
\hline 74. & Judicial & \\
\hline 75. & Respect & \\
\hline 76. & Limited & \\
\hline 77. & Ensure & ensuring \\
\hline 78. & Context & \\
\hline 79. & Issues & \\
\hline 80. & Objective & objectives \\
\hline 81. & Consumer & consumers \\
\hline 82. & Disaster & disasters \\
\hline 83. & Circumstance & Circumstance, circumstances \\
\hline 84. & Proceedings & \\
\hline 85. & Statute & Statutes \\
\hline 86. & Conflict & \\
\hline 87. & Code & codes \\
\hline 88. & Standards & \\
\hline 89. & Assistance & \\
\hline 90. & Program & programs \\
\hline
\end{tabular}




\begin{tabular}{|c|c|c|}
\hline 91. & Freedom & freedoms \\
\hline 92. & Provides & \\
\hline 93. & Capacity & capacities \\
\hline 94. & Establish & Establishes, establishing \\
\hline 95. & Request & Requested, requesting, requests \\
\hline 96. & Commercial & \\
\hline 97. & Fundamental & \\
\hline 98. & Review & \\
\hline 99. & Federal & \\
\hline 100. & Applicable & \\
\hline 101. & Circumstances & \\
\hline 102. & DER & Distinguished encoding rules \\
\hline 103. & Extent & \\
\hline 104. & TFEU & Treaty on the Functioning of European Union \\
\hline 105. & LTD & \\
\hline 106. & Jurisdiction & \\
\hline 107. & Determine & Determines, determining \\
\hline 108. & Impose & Imposed, imposes, imposing \\
\hline 109. & Interpretation & interpretations \\
\hline 110. & Compensation & \\
\hline 111. & Opinion & opinions \\
\hline 112. & Resolution & resolutions \\
\hline 113. & Instrument & instruments \\
\hline 114. & Recognize & Recognize, recognized, recognizes, recognizing \\
\hline 115. & Govern & Govern, governed, governing, governs \\
\hline 116. & Labor & \\
\hline 117. & Constitution & Constitutional, constitutions \\
\hline 118. & Matters & \\
\hline 119. & Concerning & \\
\hline 120. & Scope & \\
\hline 121. & Patent & Patented, patents \\
\hline 122. & Armed & \\
\hline 123. & Moral & \\
\hline 124. & Exempt & exempted \\
\hline 125. & Concept & \\
\hline 126. & Assessment & assessments \\
\hline 127. & Entity & entities \\
\hline 128. & Insurance & \\
\hline 129. & Supreme & \\
\hline 130. & Prevent & preventing \\
\hline 131. & Aircraft & \\
\hline 132. & Constitute & Constituted, constitutes, constituting \\
\hline 133. & Relation & \\
\hline 134. & Defendant & defendants \\
\hline 135. & Undertakings & \\
\hline 136. & Plaintiff & plaintiffs \\
\hline 137. & Institutions & \\
\hline 138. & Additional & \\
\hline 139. & Consideration & considerations \\
\hline 140. & Corporate & \\
\hline 141. & Comparative & \\
\hline 142. & Nations & \\
\hline 143. & Norm & Norm, norms \\
\hline 144. & Content & \\
\hline 145. & Guidelines & \\
\hline 146. & Exception & exceptions \\
\hline 147. & Administrative & \\
\hline 148. & Global & \\
\hline 149. & Infringement & infringements \\
\hline 150. & Practices & \\
\hline 151. & Par & "equal" In commercial law \\
\hline 152. & Conclusion & conclusions \\
\hline 153. & Criterion & criteria \\
\hline 154. & Implement & Implements, implemented, implementing \\
\hline 155. & Aspects & \\
\hline 156. & Judgment & \\
\hline 157. & Player & \\
\hline
\end{tabular}




\begin{tabular}{|c|c|c|}
\hline 158. & Permit & Permits, permitted \\
\hline 159. & Regime & regimes \\
\hline 160. & Arrest & \\
\hline 161. & Internal & \\
\hline 162. & Prohibition & prohibitions \\
\hline 163. & Definition & \\
\hline 164. & Amendment & amendments \\
\hline 165. & Implementation & \\
\hline 166. & Restriction & restrictions \\
\hline 167. & ff. & And the following pages \\
\hline 168. & Warrant & \\
\hline 169. & Dispute & disputes \\
\hline 170. & JHA & Justice and home affairs \\
\hline 171. & Prohibit & Prohibited, prohibiting, prohibits \\
\hline 172. & Ownership & \\
\hline 173. & Corporation & corporations \\
\hline 174. & Legislative & \\
\hline 175. & Introduction & \\
\hline 176. & Participation & \\
\hline 177. & Assembly & \\
\hline 178. & Shareholder & shareholders \\
\hline 179. & Intellectual & \\
\hline 180. & Prior & \\
\hline 181. & Actions & \\
\hline 182. & Operations & \\
\hline 183. & Transaction & transactions \\
\hline 184. & Enforcement & \\
\hline 185. & Agricultural & \\
\hline 186. & Draft & Drafted, drafting \\
\hline 187. & Consent & \\
\hline 188. & Relating & \\
\hline 189. & Owner & \\
\hline 190. & Accordance & \\
\hline 191. & Manner & \\
\hline 192. & Doctrine & doctrines \\
\hline 193. & Athlete & athletes \\
\hline 194. & Equal & \\
\hline 195. & Harm & Harmed, harms \\
\hline 196. & Perspective & perspectives \\
\hline 197. & $\mathrm{CTH}$ & Contract to hire \\
\hline 198. & Journal & \\
\hline 199. & Emergency & emergencies \\
\hline 200. & Citizen & citizens \\
\hline 201. & Discrimination & \\
\hline 202. & Territory & \\
\hline 203. & Governance & \\
\hline 204. & Reasonable & \\
\hline 205. & Sanction & sanctions \\
\hline 206. & Moreover & \\
\hline 207. & Regulatory & \\
\hline 208. & Competent & \\
\hline 209. & Declaration & declarations \\
\hline 210. & Minimum & \\
\hline 211. & Conclude & Concluded, concluding \\
\hline 212. & ICAO & International Civil Aviation Organization \\
\hline 213. & Compliance & \\
\hline 214. & Norms & \\
\hline 215. & Welfare & \\
\hline 216. & Mechanism & mechanisms \\
\hline 217. & Limits & \\
\hline 218. & Damages & \\
\hline 219. & Remedy & remedies \\
\hline 220. & Supra & \\
\hline 221. & Concerns & \\
\hline 222. & Undertaking & \\
\hline 223. & Republic & \\
\hline 224. & Liberty & \\
\hline
\end{tabular}




\begin{tabular}{|c|c|c|}
\hline 225. & Registration & \\
\hline 226. & Criteria & \\
\hline 227. & Athletic & athletics \\
\hline 228. & Membership & \\
\hline 229. & Accordingly & \\
\hline 230. & Participate & Participating \\
\hline 231. & Database & databases \\
\hline 232. & Promote & Promoting \\
\hline 233. & Recognized & \\
\hline 234. & Procedural & \\
\hline 235. & Lawyer & lawyers \\
\hline 236. & Entitled & \\
\hline 237. & Prisoners & \\
\hline 238. & Recommendation & recommendations \\
\hline 239. & Consequences & \\
\hline 240. & Documents & \\
\hline 241. & Breach & breaches \\
\hline 242. & Limitation & limitations \\
\hline 243. & Assets & \\
\hline 244. & Statutory & \\
\hline 245. & Granted & \\
\hline 246. & Collective & \\
\hline 247. & Physician & physicians \\
\hline 248. & Binding & \\
\hline 249. & Annex & annexes \\
\hline 250. & Societies & \\
\hline 251. & Operator & operators \\
\hline 252. & Associations & \\
\hline 253. & Registered & \\
\hline 254. & IAEA & International Atomic Energy Agency, Independent Administration of Estates Act \\
\hline 255. & Exemption & \\
\hline 256. & PTY & Proprietary, used after names of private companies in some countries \\
\hline 257. & ALIA & Affordable Life Insurance Alliance \\
\hline 258. & Shareholders & \\
\hline 259. & Restrictions & \\
\hline 260. & Pursuant & \\
\hline 261. & Enforce & Enforced, enforcing \\
\hline 262. & Execute & executing \\
\hline 263. & EFTA & European free trade association \\
\hline 264. & Sec. & section \\
\hline 265. & Crimes & \\
\hline 266. & Author & \\
\hline 267. & Agriculture & \\
\hline 268. & Genetic & genetics \\
\hline 269. & Exclusive & \\
\hline 270. & Aviation & \\
\hline 271. & REV & Real Estate Valuation \\
\hline 272. & Abuse & \\
\hline 273. & Governing & \\
\hline 274. & Directors & \\
\hline 275. & Charter & \\
\hline 276. & Furthermore & \\
\hline 277. & Namely & \\
\hline 278. & Distinction & \\
\hline 279. & Establishment & \\
\hline 280. & Violate & Violated, violates, violating \\
\hline 281. & Violation & \\
\hline 282. & License & Licenses, licensing \\
\hline 283. & Judges & \\
\hline 284. & PRO & Pro (Latin meaning in favor) \\
\hline 285. & Likewise & \\
\hline 286. & Civilian & civilians \\
\hline 287. & Situations & \\
\hline 288. & Communities & \\
\hline 289. & Employee & \\
\hline 290. & Vol & Volume \\
\hline 291. & Conflicts & \\
\hline
\end{tabular}




\begin{tabular}{|c|c|c|}
\hline 292. & Intervention & interventions \\
\hline 293. & Images & \\
\hline 294. & Autonomy & \\
\hline 295. & Merger & mergers \\
\hline 296. & Employer & \\
\hline 297. & Dominant & \\
\hline 298. & Digital & \\
\hline 299. & Institutional & \\
\hline 300. & Transactions & \\
\hline 301. & References & \\
\hline 302. & Contrary & \\
\hline 303. & Provider & providers \\
\hline 304. & Supervision & \\
\hline 305. & Audit & auditing, audits \\
\hline 306. & Submit & submitted \\
\hline 307. & WTO & \\
\hline 308. & Amended & \\
\hline 309. & Protocol & \\
\hline 310. & Comply & \\
\hline 311. & Infringe & Infringed, infringes, infringing \\
\hline 312. & Doc & docs \\
\hline 313. & Creditor & creditors \\
\hline 314. & Clause & \\
\hline 315. & Tort & torts \\
\hline 316. & Specifically & \\
\hline 317. & Comprehensive & \\
\hline 318. & Specific & \\
\hline 319. & Sovereignty & \\
\hline 320. & Charitable & \\
\hline 321. & Evaluation & evaluations \\
\hline 322. & Substantive & \\
\hline 323. & Resulting & \\
\hline 324. & Terrorism & \\
\hline 325. & Categories & \\
\hline 326. & Adequate & \\
\hline 327. & Burden & burdens \\
\hline 328. & Facilitate & facilitating \\
\hline 329. & Adoption & \\
\hline 330. & Respective & \\
\hline 331. & Behavior & \\
\hline 332. & Prevention & \\
\hline 333. & Possession & \\
\hline 334. & Mandatory & \\
\hline 335. & Arbitration & \\
\hline 336. & Deemed & \\
\hline 337. & Legitimate & \\
\hline 338. & SCE & European Cooperative Society \\
\hline 339. & EEC & European Economic community \\
\hline 340. & Violations & \\
\hline 341. & Equality & \\
\hline 342. & Invention & inventions \\
\hline 343. & Bankruptcy & \\
\hline 344. & Competence & \\
\hline 345. & Coordination & \\
\hline 346. & Economics & \\
\hline 347. & Challenges & \\
\hline 348. & Privacy & \\
\hline 349. & Issuing & \\
\hline 350. & Reasoning & \\
\hline 351. & Permitted & \\
\hline 352. & Punishment & \\
\hline 353. & Offences & \\
\hline 354. & Disclosure & \\
\hline 355. & Functioning & \\
\hline 356. & Safeguard & safeguards \\
\hline 357. & Benefit & benefits \\
\hline 358. & Ethical & \\
\hline
\end{tabular}




\begin{tabular}{|c|c|c|}
\hline 359. & Handicapped & \\
\hline 360. & Jurisprudence & \\
\hline 361. & Enterprises & \\
\hline 362. & Characteristics & \\
\hline 363. & Valid & \\
\hline 364. & Refers & \\
\hline 365. & Justify & justified \\
\hline 366. & Guidance & \\
\hline 367. & RES & Latin term for "a matter [already] judged \\
\hline 368. & Banking & \\
\hline 369. & Integration & \\
\hline 370. & Definition & definitions \\
\hline 371. & Manual & \\
\hline 372. & Regulated & \\
\hline 373. & Consequently & \\
\hline 374. & Execution & \\
\hline 375. & Addressed & \\
\hline 376. & CIR & Circuit courts \\
\hline 377. & Discretion & \\
\hline 378. & Explicitly & \\
\hline 379. & Actors & \\
\hline 380. & Online & \\
\hline 381. & Tribunal & tribunals \\
\hline 382. & Contributions & \\
\hline 383. & IRS & Internal revenue services (overlooking taxes) \\
\hline 384. & Strict & \\
\hline 385. & Chap & Chapter \\
\hline 386. & Navigation & \\
\hline 387. & Korean & \\
\hline 388. & Normative & \\
\hline 389. & Validity & \\
\hline 390. & Intent & \\
\hline 391. & Lawyers & \\
\hline 392. & Trademark & trademarks \\
\hline 393. & Uniform & \\
\hline 394. & Equity & \\
\hline 395. & Disability & disabilities \\
\hline 396. & Sovereign & \\
\hline 397. & AEUV & A German abbreviation \\
\hline 398. & Universal & \\
\hline 399. & Nonetheless & \\
\hline 400. & Negligence & \\
\hline 401. & Recommendations & \\
\hline 402. & Ethics & \\
\hline 403. & Penalties & \\
\hline 404. & Engage & engaging \\
\hline 405. & DOJ & The department of justice \\
\hline 406. & Legislature & legislatures \\
\hline 407. & Inspection & \\
\hline 408. & Governmental & \\
\hline 409. & Render & rendered \\
\hline 410. & Nutrition & \\
\hline 411. & Lex & $\begin{array}{l}\text { Lex loci. A Latin term meaning the "law of [the] place". The principle that the law of the } \\
\text { place giving rise to particular rights is the law that governs the rights of parties to a legal } \\
\text { proceeding. }\end{array}$ \\
\hline 412. & Litigation & \\
\hline 413. & Sect & Section \\
\hline 414. & Chicago & \\
\hline 415. & Limitations & \\
\hline 416. & Comprise & comprises \\
\hline 417. & Edn & Education law \\
\hline 418. & Toward & \\
\hline 419. & Appeals & \\
\hline 420. & Customary & \\
\hline 421. & Justification & justifications \\
\hline 422. & Nationality & \\
\hline 423. & Sufficient & \\
\hline
\end{tabular}




\begin{tabular}{|c|c|c|}
\hline 424. & Surrender & \\
\hline 425. & Jurisdictions & \\
\hline 426. & Implemented & \\
\hline 427. & Voting & \\
\hline 428. & Governed & \\
\hline 429. & Implementing & \\
\hline 430. & Arising & \\
\hline 431. & Representatives & \\
\hline 432. & Technologies & \\
\hline 433. & Preliminary & \\
\hline 434. & Exploitation & \\
\hline 435. & Surplus & \\
\hline 436. & Domain & \\
\hline 437. & Supp & Short for supplement \\
\hline 438. & Solely & \\
\hline 439. & Customs & \\
\hline 440. & Bargaining & \\
\hline 441. & Korea & \\
\hline 442. & Necessity & \\
\hline 443. & Facility & \\
\hline 444. & Effectiveness & \\
\hline 445. & Cited & \\
\hline 446. & Sustainable & \\
\hline 447. & Interpreted & \\
\hline 448. & Debtor & \\
\hline 449. & Recipient & recipients \\
\hline 450. & Enacted & \\
\hline 451. & Operational & \\
\hline 452. & Forum & \\
\hline 453. & Attorney & attorneys \\
\hline 454. & Defense & \\
\hline 455. & Judgments & \\
\hline 456. & Olympic & \\
\hline 457. & Supervisory & \\
\hline 458. & Geographical & \\
\hline 459. & Technological & \\
\hline 460. & fine & fines \\
\hline 461. & Autonomous & \\
\hline 462. & Expressly & \\
\hline 463. & Corresponding & \\
\hline 464. & Termination & \\
\hline 465. & Transparency & \\
\hline 466. & Exclusively & \\
\hline 467. & Enforced & \\
\hline 468. & Baseball & \\
\hline 469. & Compulsory & \\
\hline 470. & REG & Regulation \\
\hline 471. & Competitors & \\
\hline 472. & Gender & \\
\hline 473. & Unrelated & \\
\hline 474. & Peaceful & \\
\hline 475. & Conception & \\
\hline 476. & Proportionality & \\
\hline 477. & IMF & International Monetary Fund \\
\hline 478. & Responsibilities & \\
\hline 479. & Exclusion & \\
\hline 480. & Applicability & \\
\hline 481. & Decree & \\
\hline 482. & Refusal & \\
\hline 483. & Mandate & mandates \\
\hline 484. & IPR & Intellectual property \\
\hline 485. & Inherent & \\
\hline 486. & Extradition & \\
\hline 487. & Presumption & \\
\hline 488. & Basketball & \\
\hline 489. & IRC & International revenue code (a body of law that codifies all tax laws) \\
\hline 490. & Interference & \\
\hline
\end{tabular}




\begin{tabular}{|c|c|c|}
\hline 491. & Stipulates & \\
\hline 492. & Cartels & \\
\hline 493. & Vertical & \\
\hline 494. & Providers & \\
\hline 495. & Weapon & \\
\hline 496. & Investor & \\
\hline 497. & financial & \\
\hline 498. & Precedent & precedents \\
\hline
\end{tabular}

\section{Copyrights}

Copyright for this article is retained by the author, with first publication rights granted to the journal.

This is an open-access article distributed under the terms and conditions of the Creative Commons Attribution license (http://creativecommons.org/licenses/by/4.0/). 